\title{
Taming of the Shrew and England's Heiress Protection Statute Hong-li WANG
}

School of International Education, Henan Institute of Engineering, Zhengzhou, 45000, China

52453091@163.com

Keywords: Shakespeare, Taming of the shrew, Heiress, Protection statute.

\begin{abstract}
There are two plots in the Taming of the Shrew. In one plot, Petruchio marries then tames Kate. The main plot, however, is about Lucentio and Bianca. It too has a legal theme, since Lucentio plans to elope with Bianca. First, he uses fraud, allowing his servant Tranio negotiate for Bianca's dowery of 20, 000 ducats. Second, Lucentio elopes with Bianca; that is, he marries the wealthy girl in secret. The scene where he does so is often overlooked, but is very important to our understanding of the relationship between law and literature.
\end{abstract}

\section{Introduction}

There are two plots in Shakespeare's play the Taming of the Shrew. But the main plot,which Shakespeare took from Ariosto's play I Suppositi, concerns Lucentio's attempts to marry Bianc. In the source play, Lucentio has disguised himself as a servant to secretly woo Baptista's daughter. His main opposition is a very rich lawyer who also wants to marry her. There is a legal theme in the original play, since Ariosto sati-rizes the old lawyer Cleandro, who becomes Gremio, the foolish old man figure from the commedia dell'arte, who is rich but not a lawyer in Shakespeare's play. Besides mocking lawyers, Ariosto makes jokes about the customs duties that travelers had to pay when they entered Ferrara Shakespeare's play also raises legal issues. When Petruchio marries Kate he declares that she is his property, giving him the right to do with her as he pleases. The marriage of Bianca depends on the legal document that Bapista, the father, demands that will guarantee that his daughter will receive her marriage portion from Lucen-tio's father's land if she becomes a widow. But Lucentio's elopement would also have been illegal in another way. Not only was he going to use a false signature to win Baptista's daughter and 20,000 crowns that is probably her dowry the amount Baptista promises Petruchio for marrying Katerina, but he also in-tended to marry this wealthy girl in secret. In England such an elopement by a fortune hunter was the subject of a statute, which tried to prevent men from marrying wealthy women without the permission of their fathers.

\section{The Statute Protection}

The statute could not prevent the marriage. Once a girl was married, she stayed married. But the statute did try to block the fortune hunter from getting the heiress's money. That is exactly what happens in the play, but in a dramatic, not a legal fashion. Lucentio marries Bi-anca, but as far as we know he never receives the dowery of 20,000 ducats that Petruchio gets for marrying Katharina. Moreover he loses a very expensive bet at the wedding dinner that he, not his father in law, pays for ( since the feast takes place in Lucentio's house. In the end, he finds himself in the position that he would have been in under 4,5 Ph. and Mary c 8, which is bad luck for him, since in England,the statute did not work. This statute and Shakespeare's play illustrate both a 
broad and a narrow connection between law and literature. The law can help us discern what fictions like novels, plays, poems, or films are actually doing. To our eyes the important issue in The Taming of the Shrew is Petruchio's treatment of Katherina. But it is arguable that this secondary plot, although it gives the play its title, also took second place to the issues of the Lucentio plot, which focuses on the perils that face a fortune hunter as he tries to win a wealthy girl away from her father. Shakespeare himself married an heiress after getting her pregnant, the very situation the heiress protection statute was designed to prevent, although since Anne Hathaway was twenty-six years old at the time, she was well outside the provisions of the statute. The statute only applied to women under sixteen. A consciousness of the law designed to protect heiresses alerts us to the importance of the Lucentio plot in the Taming of the Shrew, a plot that is often ignored. Lucentio does not even appear in the old black and white Mary Pickford-Douglas Fairbanks film version of The Taming of the Shrew. Lucentio does not have to figure out ways around Baptista's decree that Bianca can marry only after Kate has found a husband, so there is no fraudulent deception of the father and no elopement. This narrowing of the play misses the importance of fraud in Shakespeare's culture. A narrow approach that concentrates on legal history can correct our blindness to the important theme of fraud in The Taming of the Shrew. Statutes are important documents that need to be carefully read to be understood. They also produced case histories, where we can see judges trying to apply the legal language of the statutes. In England statutes contributed to the Common Law, which was determined by a combination of statutes, cases, and customs. The idea was that no one person in his lifetime could attain the wisdom that had accumulated over the centuries; therefore even statutory language had to be understood in a legal context.

In general criminal statutes were read narrowly, because harsh penalties demanded strict proof that a crime had been committed, but non-criminal laws, like the laws against fraud, were read broadly, because judges knew that no statute could cover all the types of fraud that men were capable of conceiving. The heiress protection statute, which falls somewhere in between, shows the futility of a law against fortune hunters like Lu-centio, whose cleverness is illustrated by the complex but not impossible plot of Shakespeare's play. Even though the heiress protection statute seems to have been ineffective, if we look at it only in terms of legal history, it alerts us to the issue of fraud in the Lucentio-Bianca plot in The Taming of the Shrew. A narrow look at the language of the statute further alerts us to the nature of the fraud that the Lucentio plot illustrates. The statute makes it illegal to "convey" away women "against the will of the father." The word convey alerts us to what is at stake, since it echoes the language of fraudulent conveyance. At the time of Queen Mary there was no effective statute on the books to protect creditors against deceiving debtors. Although there had been attempts to prevent this fraud, the legal language necessary would not be crafted until 1571 when the statute 13 Eliz. 5 was passed, and the statute itself would not attain its final status until clarified by a judicial decision in Twyne's case in 1601, when the statute became so effective that it remains the law in England and America to this day. The language of fraudulent conveyancing that occurs in the heiress protection statute suggests the cultural issues involved in the heiress protection.

\section{Katharina's Marriage}

One aspect is literary and focuses on the marrying Katharina. Moreover he loses a very expensive bet at the wedding dinner that he, not his father in law, pays for ( since the feast takes place in Lucentio's house,5. 2. 8). In the end, he finds himself in the 
position that he would have been in under 4,5 $\mathrm{Ph}$. and Mary c 8, which is bad luck for him, since in England, the statute did not work. This statute and Shakespeare's play illustrate both a broad and a narrow connection between law and literature. The law can help us discern what fictions like novels, plays, poems, or films are actually doing. To our eyes the important issue in The Taming of the Shrew is Petruchio's treatment of Katherina. But it is arguable that this secondary plot, although it gives the play its title, also took second place to the issues of the Lucentio plot, which focuses on the perils that face a fortune hunter as he tries to win a wealthy girl away from her father. Shakespeare himself married an heiress after getting her pregnant, the very situation the heiress protection statute was designed to prevent, although since Anne Hathaway was twenty-six years old at the time, she was well outside the provisions of the statute. The statute only applied to women under sixteen. A consciousness of the law designed to protect heiresses alerts us to the importance of the Lu-centio plot in The Taming of the Shrew, a plot that is often ignored. Lucentio does not even appear in the old black and white Mary Pickford-Douglas Fairbanks film version of The Taming of the Shrew. Lucentio does not have to figure out ways around Baptista's decree that Bianca can marry only after Kate has found a husband, so there is no fraudulent deception of the father and no elopement. This narrowing of the play misses the importance of fraud in Shakespeare's culture. A narrow approach that concentrates on legal history can correct our blindness to the important theme of fraud in The Taming of the Shrew. Statutes are important documents that need to be carefully read to be understood. They also produced case histories, where we can see judges trying to apply the legal language of the statutes. In England statutes contributed to the Common Law, which was determined by a combination of statutes, cases, and customs. The idea was that no one person in his lifetime could attain the wisdom that had accumulated over the centuries; therefore even statutory language had to be understood in a legal context. In general criminal statutes were read narrowly, because harsh penalties demanded strict proof that a crime had been committed, but non-criminal laws, like the laws against fraud, were read broadly, because judges knew that no statute could cover all the types of fraud that men were capable of conceiving.

\section{The Heiress Protection Statute}

The heiress protection statute, which falls somewhere in between, shows the futility of a law against fortune hunters like Lucentio, whose cleverness is illustrated by the complex but not impossible plot of Shakespeare's play. Even though the heiress protection statute seems to have been ineffective, if we look at it only in terms of legal history, it alerts us to the issue of fraud in the Lucentio-Bianca plot in The Taming of the Shrew. A narrow look at the language of the statute further alerts us to the nature of the fraud that the Lucentio plot illustrates. The statute makes it illegal to "convey" away women "against the will of the father." The word convey alerts us to what is at stake, since it echoes the language of fraudulent conveyance. At the time of Queen Mary there was no effective statute on the books to protect creditors against deceiving debtors. Although there had been attempts to prevent this fraud, the legal language necessary would not be crafted until 1571 when the statute 13 Eliz.5 was passed, and the statute itself would not attain its final status until clarified by a judicial decision in Twyne's case in 1601, when the statute became so effective that it remains the law in England and America to this day. The language of fraudulent conveyancing that occurs in the heiress protection statute suggests the cultural issues involved in the heiress protection. One aspect is literary and focuses on the folks. 
The penalty follows the remedy. If the offender is over fourteen years of age, he and his confederates will be imprisoned for two years or fined, an amount to be determined in Star Chamber. If the offender deflowers the girl or contracts matrimony, he shall be imprisoned for five years or pay a fine, half to the Crown, half to "the parties grieved." The statute does not otherwise annul the marriage, probably because the determination of marriage (based on the woman's consent) was a matter for the ecclesiastical courts. If the statute does not restore the ravished and married woman to her previous status, it does seek to frustrate the new husband's claims to the family property. First, aware that no Common Law suit could proceed without the proper pleading, the authors of the statute specified that the correct procedure against the malefactor was an "indictment of trespass." They then specified that where the woman consented to matrimony, and so was married, her property would pass to her next of kin during her lifetime, a restatement of the law in 6 Rich.3,c.6. Matrimony. It is hard to know what is most scandalous: the danger of abduction that this statute was designed to counter; the poor drafting of the statute; or the exceptions that it allowed. First, it applies only to women under sixteen years of age. At a time when women routinely married in their twenties, as Peter Laslett argued in The World We Have Lost, the statute failed to cover a significant portion of the population. The statute further exempts London or any other municipality that provides for orphans. If they, like the Court of Wards that controlled most of the great heiress of the realm, allowed fortune hunters, that was their business. Finally, the pressures operating against this statute are signaled by the exceptions made for matrimonial contracts made by "such person or persons as by the title of Wardship shall then have, or be entitled to have, the marriage of such maid or woman child." This statute allowed old lords to marry young wards. It is perhaps not just the spirit of comedy but the ineffective state of the law that accounts forso many protective fathers or appointed guardians in Shakespeare's plays: Capulet, Brabantio, Aegeus, Prospero, Calchas, Baptista Minola, the Duke of Milan in Two Gentlemen of Verona, Shylock, George Page, Leonato, Lear, Polonius, Duke Frederick and Duke Senior, and, lest we not take seriously the worries of parents, whoever is responsible for Thisby. Despite the foolishness of most of these men, some of Shakespeare's young women are fatherless and, if the concerns of 4,5 Philip \& Mary c 8 are any indication of the dangers that faced them, Shakespeare's audience would have perceived them as imperiled and unprotected. This list includes Juliet, demona, Hermia, Miranda, Jessica, Bianca and her sister Kate, and Sidney's heroines Pamela and Philoclea.

\section{Conclusion}

A major problem is that the statute contains an emotional but legally ineffective definition of fraud, using name calling and outrage in place of logic. For example, the penalty provision makes the mistake of incompletely specifying the types of fraud a man might use to gain the consent of an underage woman - that is, "by secret letters, messages, or otherwise." The word "otherwise" raises a problem that a good lawyer, then or now, might exploit. Suppose that a father, like Brabantio, believes a man has used black magic to seduce his daughter. His lawyer would argue that the word "otherwise" covers magic, but the opposing lawyer would argue that it does not. Magic is not a means of communication, like letters or messages, since it is done in secret and the recipient is unaware of this secret means of persuasion. Lacking case law on this statute, we don't know if the issue was alive, but Shakespeare's Othello inverts the Marian statute. The Duke is prepared to void the marriage should it be 
shown that Othello used magic to lure Desdemona, but as Othello only used his words, his action does not fit the duke's category: in the play, as opposed to the statute, it does not suffice that the messages of love are secret. Like Brabantio, the statute expresses outrage but proves powerless. Unlike the statute, Shakespeare concentrates on Desdemona's marital status and her father's personal, not financial, disappointment. The play avoids the issue of Desdemona's property and fraud.

\section{References}

[1] Laslett, Peter. The World We Have Lost: England Before the Industrial Age. 2nd ed. New York: Scribner's, 1971.

[2] Shakespeare, William. The Taming of the Shrew: The Riverside Shakespeare. Ed. Blakemore G. Evans. Boston: Houghton Mifflin Company, 1974. 